\title{
First Record of Lepista sordida (Schumach) Singer in Eastern North Africa
}

\author{
A.A. El-Fallal, A.K.A. El-Sayed and H.M. El-Gharabawy ${ }^{\#}$ \\ Botany \& Microbiology Department, Faculty of Science, Damietta University, \\ Damietta El-Gededa, PO 34517, Egypt.
}

\begin{abstract}
$\mathbf{A}^{2}$ NEW record of Lepista sordida was collected from a lemon fruit farm in El-Sinania at Damietta District of North delta of Egypt in December, 2014. It was identified using morphological (macro and microscopic) and molecular techniques. Complete description was preformed for the collected fresh fruiting bodies and isolated pure culture. Radial growth rate of culture was estimated on Potato dextrose and Malt extract agar media $(8.5 \& 7.8 \mathrm{~mm} /$ day, respectively). Lepista sordida and L. nuda are very close in morphological characters; hence, the identification was confirmed by DNA sequence analysis of the ribosomal 5.8S rRNA gene including the flanking internal transcribed spacers (ITS). Then, its taxonomic position among some genera of Tricholomataceae and its relation with some other Lepista species was discussed. The surrounding habitat was also observed and environmental conditions were recorded as Temperature degree $\left(29.7^{\circ} \mathrm{C}\right)$, relative humidity (RH: 44.6$)$ and soil moisture was (5.56). Lepista sordida was reported from South Africa and Nigeria (in the South), Algeria and Tunisia (in the North-west) and this is first record in North-East Africa.
\end{abstract}

Keywords: Tricholomataceae, Lepista sp., Edible mushroom, Morphological identification, Phylogenetic tree, ITS DNA sequencing.

\section{Introduction}

Lepista (Tricholomataceae) is a widespread genus, with many edible species such as $L$. sordida, $L$. nuda and L. saeva (Stott, 1998). Those mushroom species are relatively popular in Europe, America and Australia (Moser, 1978; Breitenbach \& Kranzlin, 1991; Young, 1994 and Davis et al., 2012) but rare in Africa except Nigeria and South Africa (Ekwebelam, 1980 and Popich, 2014). Lepista sordida (Schumach) Singer was reported from Algeria and Tunisia (north-west Africa) in Q. ilex woods (Malençon \& Bertault, 19701975). This species was also reported by Contu \& Signorello (1999) from Sicily in Eucalyptus woods. There is no any record for L. sordida in north-east Africa.

Some of Lepista species have commercial potentials. L. nuda presents antioxidant properties (Murcia et al., 2002) and antibiotic activities against many bacteria (Dulger et al., 2002). Besides, L. sordida produces two diterpenes that induce differentiation in human leukemic cells (Mazur et al., 1996). Polysaccharides extracted from $L$. sordida possessed potent ant proliferative effect on mice and human laryngeal carcinoma Hep-2 cells (Miao et al., 2013), also had antioxidant activity and retard aging effects (Zhong et al., 2013). Those medicinally important polysaccharides could be used as a potential natural antitumor drug and attenuate age-related diseases in humans.

Remarkable evolution has been made to affirm phylogenetic relationships in the largest order; Agaricales (Moncalvo et al., 2002; Garnica et al., 2007 and Binder et al., 2010). However, continued assessment of evolutionary relationships within this order is necessary. Also, the species of Lepista and some other Tricholomataceae are somewhat difficult to be differentiated by morphological descriptions. So, molecular techniques such as ribosomal RNA gene sequencing had been developed for their identification (Stott, 1998 and Stott et al., 2005).

The aim of the study is to advance the current knowledge of morphology, and molecular analysis of an Egyptian Lepista mushroom that grows in El-Sinania Farms at Damietta - Egypt.

\#Corresponding author email: hoda_mohamed@du.edu.eg. Tel.: 572403866; Fax: +2057403868; Mob.: 01004389299, DOI :10.21608/ejbo.2017.980.1087

(C)2017 National Information and Documentation Center (NIDOC) 


\section{Materials and Methods}

\section{Morphology and identification}

Descriptions of basidiomes were made according to their external and internal morphology. For external morphology the material was observed for colour, texture, gills morphology, margin, and pileal surface of basidiocarp. For internal morphology, thin hand sections were taken from pileus passing through gills, and mounted in also in Melzer's reagent (Beneke, 1958).

The slides were observed under Optika B-350 compound microscope having a combination of 10x eyepiece and 10x, 45x and oil immersion (100x), objectives. Photographs were taken using Canon digital camera. Measurements of basidiospores were taken using objective micrometer or calibrated ocular.

Isolation into pure culture was carried out directly after collection from the field sites according to the method of El-Gharabawy et al. (2016). Small pieces of either inner layers of the fruiting body tissue were cultured on to plates of potato dextrose agar (PDA), 2\% malt extract agar (MA) under sterile conditions. Isolation plates were incubated at $25^{\circ} \mathrm{C}$ and pure cultures were maintained on PDA slopes at $4^{\circ} \mathrm{C}$. Radial growth rate (RGR) was quantified on $9 \mathrm{~cm}$ Petridishes of PDA and $2 \%$ MA using $1 \mathrm{~cm}$ discs of actively growing cultures at $25^{\circ} \mathrm{C}$.

\section{DNA extraction}

Genomic DNA was extracted according to the procedure of Lee \& Taylor (1990) with some modifications. Fresh fruiting body was washed with sterile water and frozen with liquid nitrogen followed by grinding with sterilized sonicator. Then $500 \mu \mathrm{l}$ extraction buffer (Equal volume of $50 \mathrm{mM}$ Tris- $\mathrm{HCl}(\mathrm{pH} 7.5), 50 \mathrm{mM}$ EDTA (pH 8.0) and 1\% SDS (Sodium Dodecyl Sulphate) was added to the micro tube sample and incubated at $65^{\circ} \mathrm{C}$ for $30 \mathrm{~min}$. After incubation the same volume of (25 Phenol: 24 Chloroform: 1 Isoamyl-alcohol) mixture was added, mixed by inverting the tubes and centrifuged at $4^{\circ} \mathrm{C}$ for 10 $\min$ at $12000 \mathrm{rpm}$. The DNA in the supernatant was precipitated by isopropanol, washed with $75 \%$ ethanol, resuspended in water free nuclease and then stored at $-20^{\circ} \mathrm{C}$ until used for PCR amplification.

PCR amplification and sequencing of ITS-5.8S $r R N A$ region

The oligonucleotide primers (ITS4: ${ }^{5}$ TCCTCCGCTTATTGATATGC ${ }^{\prime \prime}$ and ITS5: ${ }^{\prime}$ GGAAG-
TAAAAGTCGTAACAAGG ${ }^{3}$ ') used for amplification and sequencing of the 5.8S rRNA-ITS regions (White et al., 1990) were made by BIONEER, South Korea.

PCR reaction was carried out using a thermal cycler (TECHENE model FTC3102, UK). PCR mixture consisted of $4 \mu 1$ of each primer $(20$ mole $\left.\mathrm{ml}^{-1}\right), 1 \mu \mathrm{l}$ of genomic DNA and $25 \mu 1$ Dream Taq (Thermo scientific- Green PCR Master Mix) to a final volume of $50 \mu \mathrm{l}$. PCR was performed with initial denaturation at $94^{\circ} \mathrm{C}$ for $5 \mathrm{~min}$, followed by 35 cycles at $94^{\circ} \mathrm{C}$ for $1 \mathrm{~min}, 55^{\circ} \mathrm{C}$ for $1 \mathrm{~min}$ and $72^{\circ} \mathrm{C}$ for $2 \mathrm{~min}$, then final extension at $72^{\circ} \mathrm{C}$ for 10 min. The PCR product was then sequenced using the same ITS4/ITS5 primers by ABI 3730XL DNA Analyzer at Macrogen, South Korea.

Alignment and phylogenetic analyses

Obtained ITS nucleotide sequences were subjected to a BLAST search against the NCBI database (http://www.ncbi.nlm.nih.gov/) to match the best similarities with other related ITSs on database (Altschul et al., 1990, 1997). The best DNA sequence similarities with our ITS region were obtained from NCBI GenBank and aligned using CLUSTAL W (Thompson et al., 1994). Unalignable regions were excluded manually and the sequences from the same species and unidentified organisms were discarded. Finally, Phylogenetic tree analysis was done using MEGA version 4 (Tamura et al., 2007). The neighborjoining was performed using the maximum composite likelihood methods (Tamura \& Nei, 1993). The bootstrap values of 50 or above were only considered and represented next to the phylogenetic tree branches with confidence levels estimated by 1000 bootstrap replicates.

\section{Results}

Morphological characteristics

The taxonomic position: Fungi Basidiomycota - Agaricomycetes - Agaricales Tricholomataceae.

Habitat: The fruit bodies were saprobic, gregarious and form a fairy ring, on soil and in mixed lawn and usually in areas where leaf litter collects (Fig. 1A \& B). The Lepista isolate had the code of EGDA2 strain (refers to Egypt, Damietta where it found). The samples were collected during field trip to El-Senania lemon fruit farms at Damietta district in $16^{\text {th }}$ of December 2014 , at N $31.4403^{\circ}$, E $31.7776^{\circ}$. Temperature was $29.7^{\circ} \mathrm{C}$, relative humidity $(\mathrm{RH})$ was 44.6 and the soil moisture was 5.56 . 


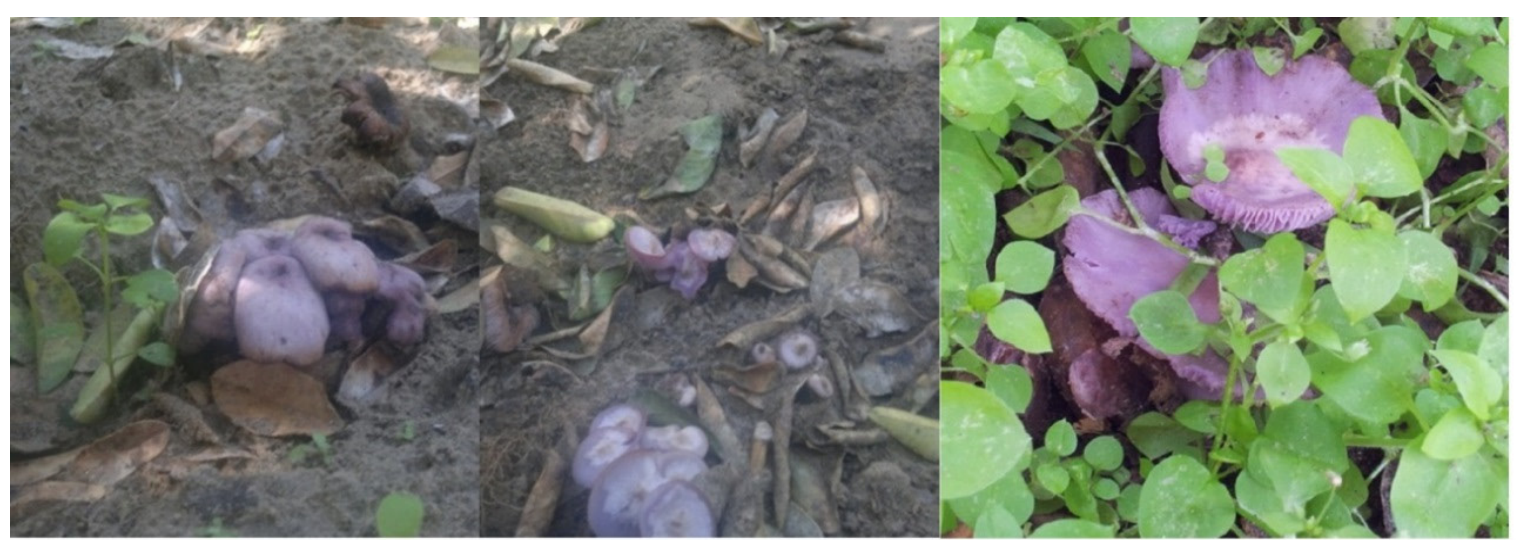

A

B
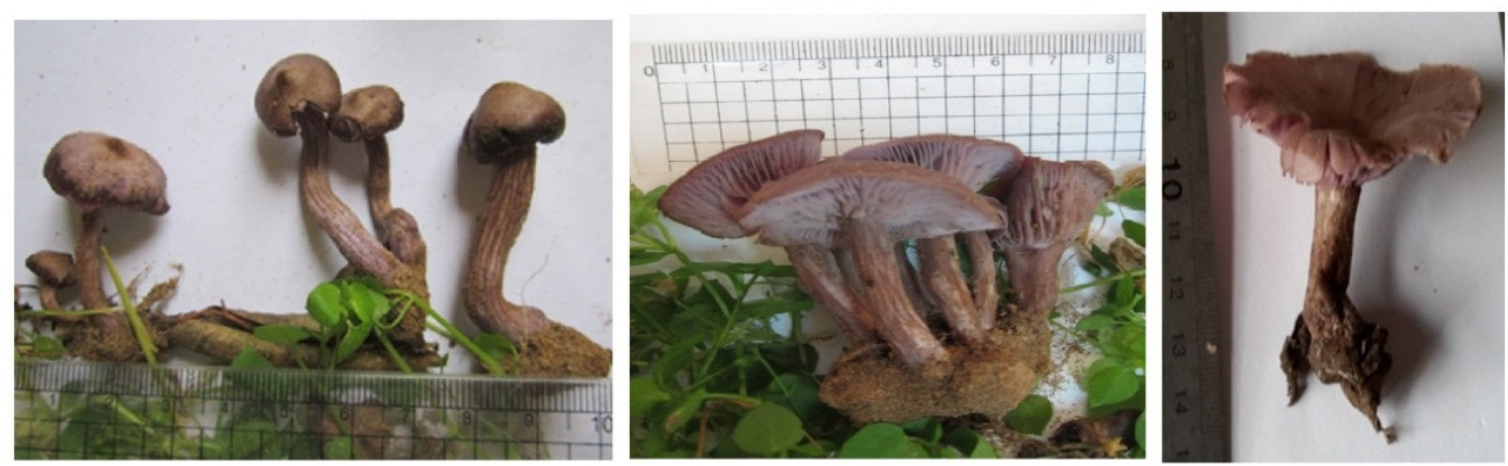

C

D

$\mathbf{E}$
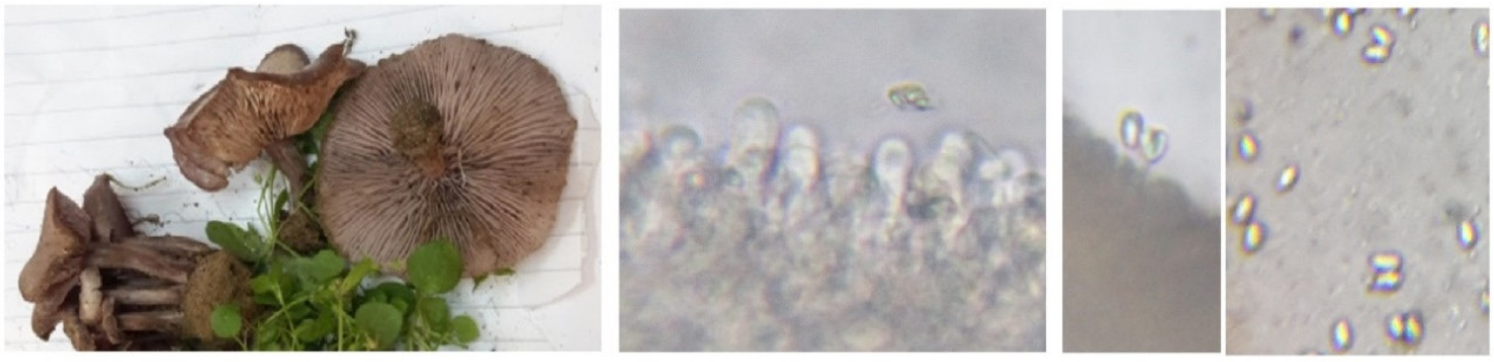

$\mathbf{F}$

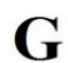

$\mathbf{H}$

Fig. 1. Fruit body external morphology of $L$. sordida EGDA2 in the field gregarious and form a fairy ring (A \& B), Cap is convex with a slight umbo (C) flattening out or developing a central depression with in-rolled margin (D \& E). Gills sinuate or emarginate and crowded (F). Basidia (G) and basidiospores (H).

Description: The basidiocarp is deep violet colour with a thin cap margin. At maturity it is not distinguishable from Lepista nuda. Cap is 2 to $6 \mathrm{~cm}$ across; initially convex sometimes with a slight umbo (Fig. 1C), flattening out or developing a central depression at maturity (Fig. $1 \mathrm{D}, \mathrm{E})$, usually with a slightly a wavy margin and in-rolled; deep lilac, turning brown from the centre in dry weather. Cap surface is smooth not sticky even in moist weather. Gills sinuate or emarginated and crowded (Fig. 1E \& F), the gills are initially greyish lilac fading to buff with age. Stem is 2 to $4 \mathrm{~cm}$ long and 4 to $10 \mathrm{~mm}$ in diameter; fibrillose; lilac; downy and white at base with no ring. Basidia are narrow, clavate (Fig. 1G) with parallel trama, 2 or 4 spored. Spores are ellipsoidal, 6-9 by 4-5 $\mu \mathrm{m}$ (Fig. $1 \mathrm{H}$ ) nonamyloid, colourless, hyaline, thin walled, roughened and ornamented with tiny spines. Spore print is creamy-white. 
The pure culture of this species is white with faster radial growth rate on PDA $(8.5 \mathrm{~mm} /$ day $)$ than on MA (7.8 mm/ day) (Fig. 2). Mycelium colonized all the Petridish within 8 days of incubation. Culture showed more aggressive
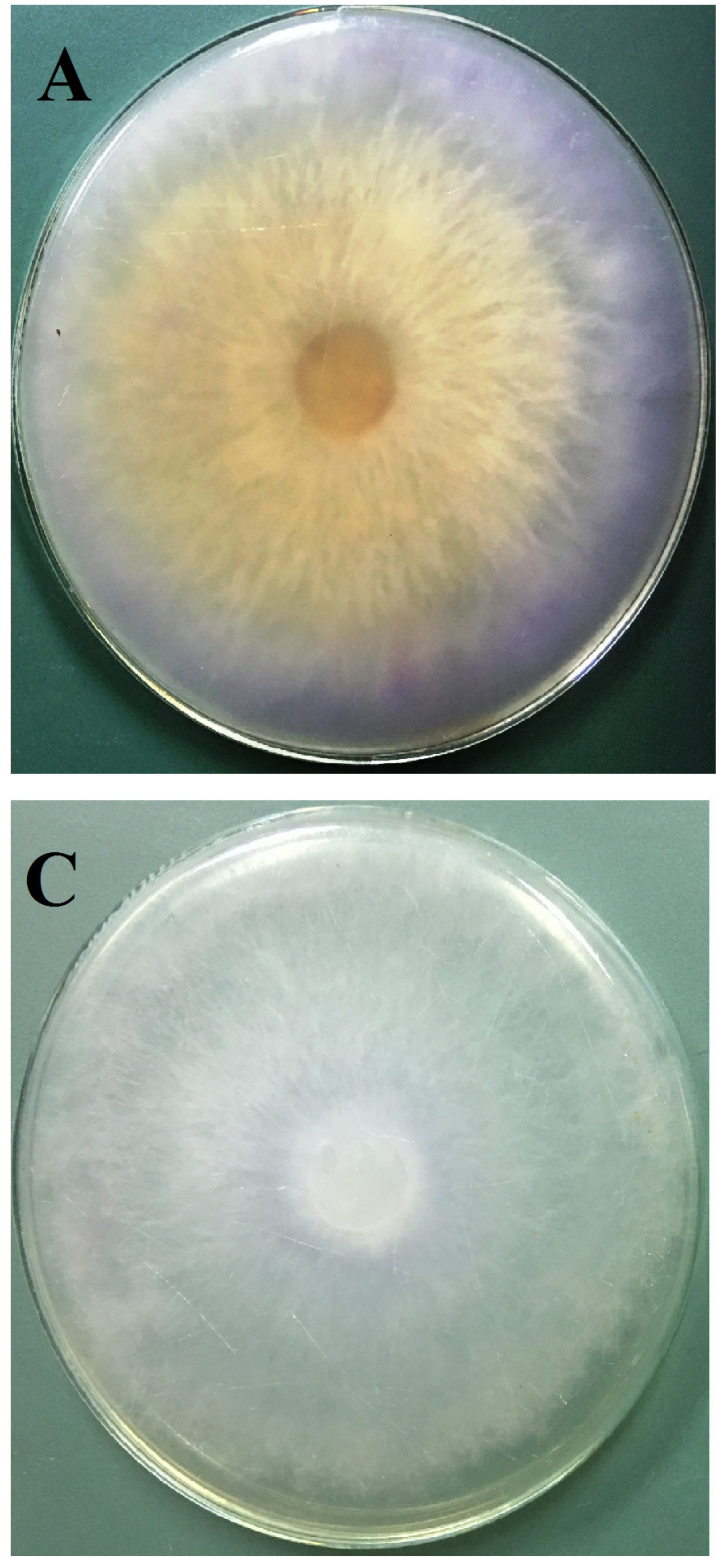

Fig.2. Culture of Lepista sordida EGDA2 growing on PDA (A \& B) and MA(C \& D).

\section{ITS based identification}

The PCR product sequencing of the ITSI-5.8SITSII rDNA region for $L$. sordida EGDA2 revealed $663 \mathrm{bp}$, which were submitted in the GenBank with accession number LN827702. The DNA sequence alignment of the studied ITS region for $L$. sordida EGDA2 showed the highest identity (100\%) with L. sordida (KF874612) and (99\%) with L. sordida (KJ137272). Some other different L. sordida and
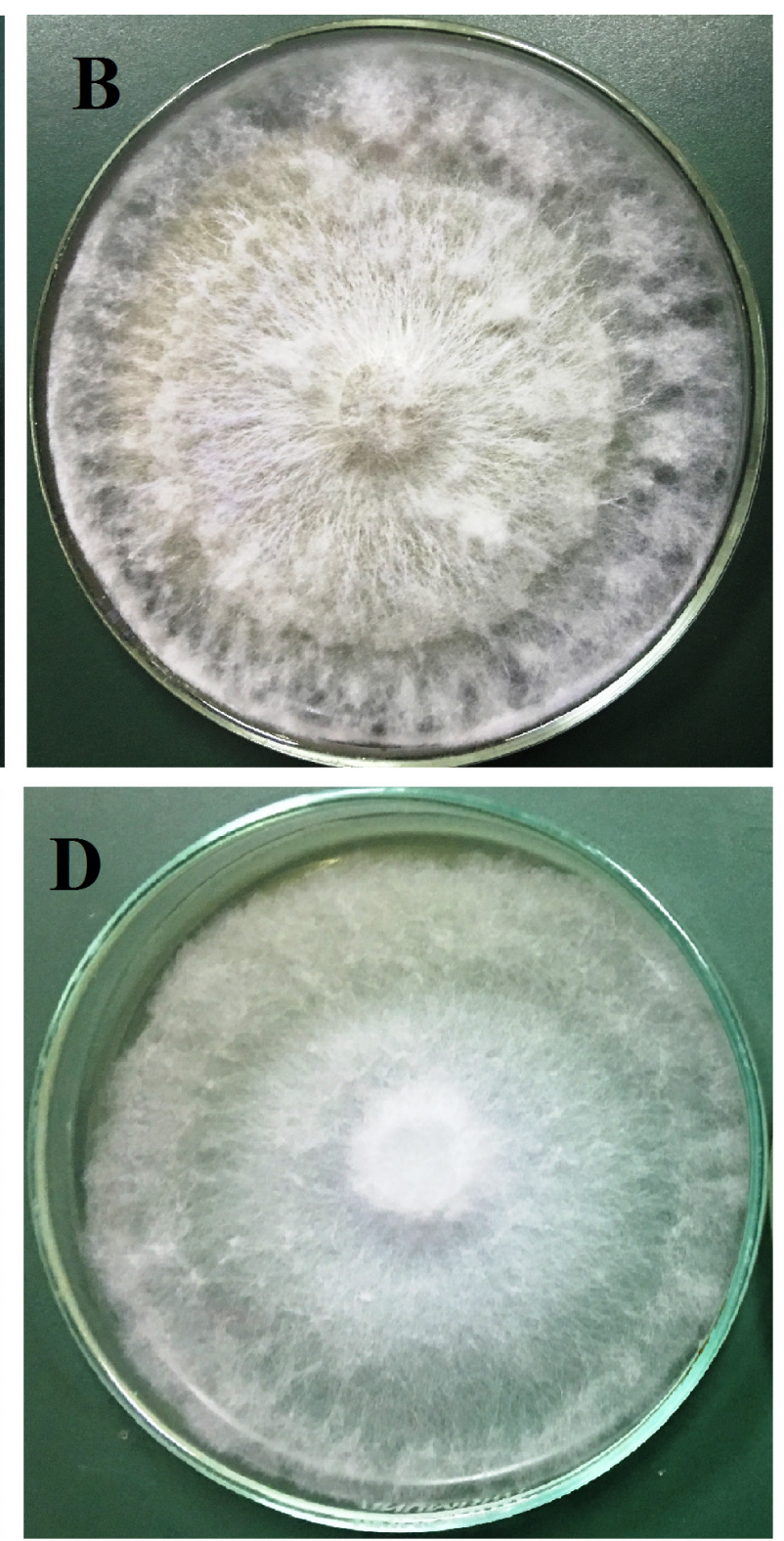

appearance on PDA as oyster mushrooms with thick growing tenacious mycelium and fluffy cottony surface. It also pins readily and easily on agar with pale violet reverse.

L. tarda strains showed less similarities reached 95\%-98\%. Also, it exhibited 94\%-95\% identity with $L$. nuda, L. saevaand L. personata strains. Tricholoma mongolicum isoletes aligned with our strain at $96 \%$ identity, while different species of Clitocybe, Collybia and Lyophyllum showed 94\%$95 \%$ similarities. All the previously mentioned alignments were significant as they possessed E value 0.0 using Blast program. 
The phylogenetic tree based on ITS DNA sequence (Fig.3) clustered L. sordida EGDA2 in one clade with some other isolates of the same L. sordida species possessing approximate dissimilarity distance reached 0.015 with Tricholoma mongolicum clade.

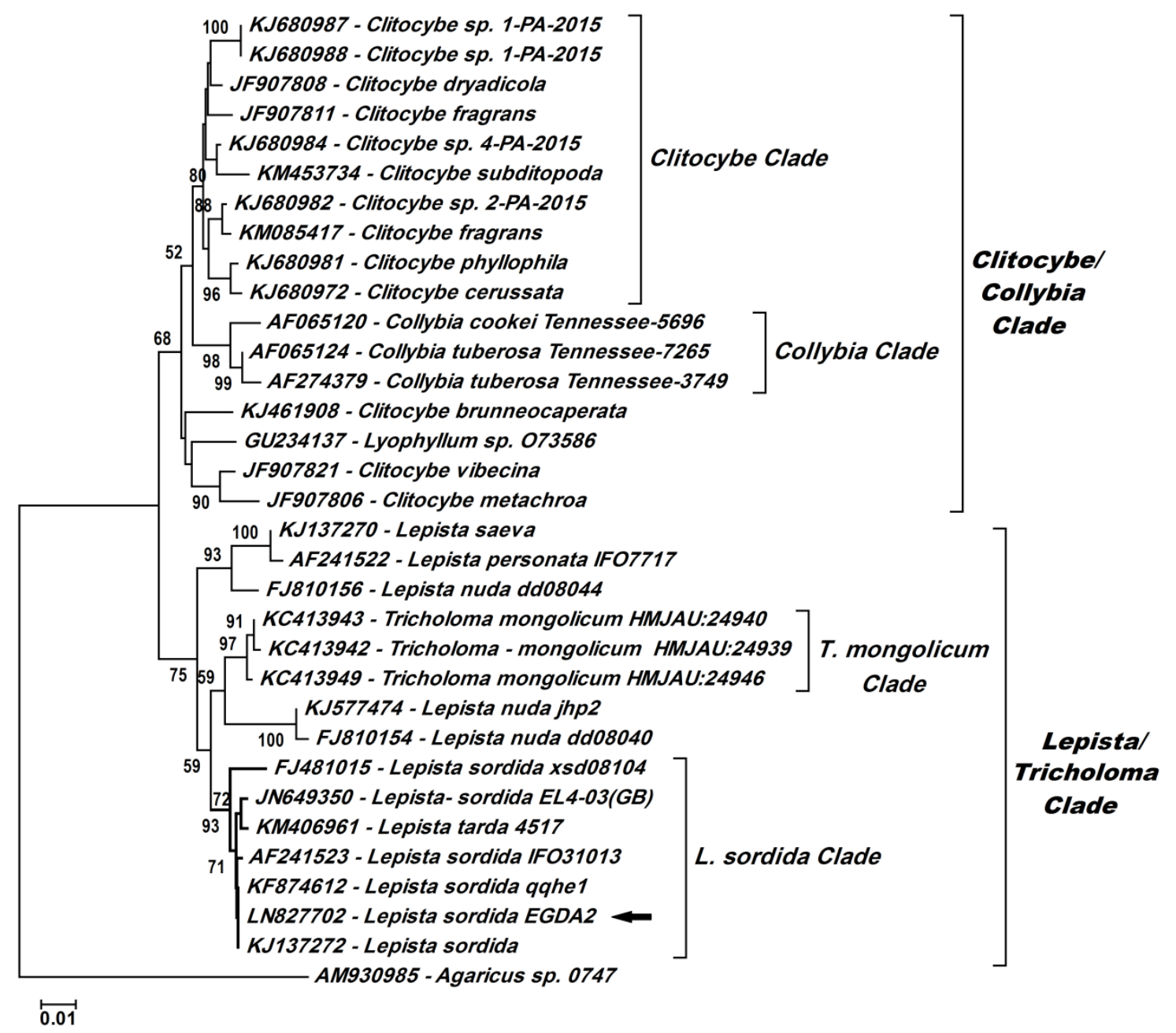

Fig. 3. Phylogenetic tree analysis based on the ITS1-5.8S-ITS2rDNA sequence alignment for L. sordida EGDA2 (AC: LN827702) with some other related genera and lepista species which possessed the best similarity. The ITS sequence of Agaricussp (AC: AM930985) was used as outgroup to root the tree. The bootstrap values 50 or above were represented next to the phylogenetic tree branches.

\section{Discussion}

Lepista sordida (Schumach) Singer is a basidiomycete fungus that produces an excellent tasting light purple mushroom. L. sordida usually occurs so late in the season than other mushroom, it was observed growing in December and late winter in current study. Tricholomataceae was only represented by Lyophyllum buxeum in the North East Nile delta (El-Fallal, 2003, 2013), until we recorded $L$. sordida EGDA2 isolate in 2014. However, Lyophyllum is now belonging to Lyophyllaceae (Species Fungorum, 2013). The identification of the genus Lepista looks almost, but not quite like either a Tricholoma or a Clitocybe. Its cap is soft fleshy and gills are attached to a fleshy stem. The stem is central and fibrous (when broken, fibers leave a ragged edge) with no ring. Although Tricholoma species typically have gills notched at the stem, as do several Lepista species, the spores of Tricholoma are white, never colored, whereas $L$. sordida produces roughened pale buff or pinkish-buff basidiospores. Tricholoma caps never change color on drying; in several Lepista species color does so change. Young Tricholoma cap margins typically incurve, young Lepista cap margins typically inroll. Tricholoma species do not have purple colors; whitish Tricholomas 
are grayish while whitish Lepistas are typically brownish or buff tinged.

L. sordida is an attractive mushroom; its flesh has striking lilac to violet colour when young while the caps may take on a brown colour and begin to fade from the centre toward the margin with age. Because of its purple colours, late appearance and lack of any association with trees L. sordida is fairly easy to identify. It is probably most similar in morphological characters to the closely related L. nuda, however, L. sordida is more slender than L. nuda and has more of a tendency to grow in clusters, as is seen in Fig. 1. Hence, more criteria are required as ITS analysis for accurate differentiation.

Interestingly, the phylogenetic tree based on the ITS sequencing clustered L. sordida EGDA2 with Tricholoma mongolicum, which is morphologically different, in the same Lepista clade. The same observation was recorded by $\mathrm{Yu}$ et al. (2011) who renamed T. mongolicum to Leucocalocybe mongolicum which clustered with Lepista irina.

The ITS phylogram analysis for some agaric fungi showed also that L. sordida and L. nuda were in the same clade with L. mongolicum and closely clustered with some species of Clitocybe and Collybia (Cooper, 2014). However, Clitocybe species typically have gills running down the stem and in-rolled cap margins. Lepista species with such characteristics may not be readily distinguished, except that if gills run down stem, they are nearly always short decurrent. White, buff and pinkish tan colors are common to both genera. Furthermore, Clitocybe species have no purple colors. Most Lepista species have a growth habit that is clustered, sub-clustered or at least gregarious. Only $C$. dilatata in genus Clitocybe appears to have a clustered growth habit. In the Pacific Northwest species, Clitocybe has white spores while Lepista has pale pinkish buff or pinkish buff spores (Bigelow, 1982, 1985). It was not surprise to find that L. tarda and L. sordida EGDA2 were located in the same clade as they are morphologically similar except that $L$. tarda stem is tapering (Butler, 2004).

Lepista. sordida as a valuable edible and medicinal mushroom is widespread in northern temperate zones throughout the world (Terashima \& Fujiie, 2005). L. sordida was successfully cultivated for the first time in Thailand from a wild strain (Thongbai et al., 2017). This strain was identified by morphological description and ITS molecular technique and a temperature of 25 - 30 ${ }^{\circ} \mathrm{C}$ was the best for mycelial growth. L. sordida, as a fairy-ring-forming fungus, was examined for its effect on the growth of turfgrass in Japan (Terashima \& Fujiie, 2007). A plant growthstimulating compound, 2-azahypoxanthine (AHX) was purified from its culture found to promote the growth of plant roots (Choi et al., 2010). Furthermore, L. sordida proved active role in lignin degradation, dye removal and other industrial applications. Laccases produced by $L$. sordida was characterized by Cavallazzi et al. (2004).

In conclusion, the combination of the ITS sequence analysis and morphological characters confirmed that the Lepista sp. isolated from Damietta District at North East Nile delta is belonging to $L$. sordida species. It is also more related to L. tarda and T. mongolicum ( $L$. mongolicum) than Clitocybe and Collybia spesies.

\section{References}

Altschul, S.F., Gish, W., Miller, W., Myers, E.W. and Lipman, D.J. (1990) Basic local alignment search tool. Journal of Molecular Biology, 215, 403-410.

Altschul, S.F., Madden, T.L., Schaffer, A.A., Zhang, J., Zhang, Z., Miller, W and Lipman, D.J. (1997) Gapped BLAST and PSI-BLAST: A new generation of protein database search programs. Nucleic Acids Research, 25(17), 3389-3402.

Beneke, E.S. (1958) "Laboratory Manual of Medical Mycology" 86, pp.1-13.

Bigelow, H.E. (1982) "North American Species of Clitocybe," Part 1. Vaduz, West Germany: J. Cramer.

Bigelow, H.E. (1985) "North American Species of Clitocybe," Part 2. Vaduz, West Germany: J. Cramer.

Binder, M., Larsson, K.H., Matheny, P.B. and Hibbett, D.S. (2010) Amylocorticiales ord. nov. and Jaapiales ord. nov.: early-diverging clades of Agaricomycetidae dominated by corticioid forms. Mycologia, 102, 865-880.

Breitenbach, J. and Kranzlin, F. (1991) "Fungi of Switzerland", Vol. 3., Boletes and Agarics (Ed.), pp. 214- 216, $1^{\text {st }}$ part. ed. Mykologia, Lucerne, Switzerland.

Butler, G. (2004) Trial field key to species of the genus Lepista and related species. http://www.svims.ca/ council/Lepist.htm.

Cavallazzi, J.R.P., Oliveira, M.G.D.A. and Kasuya, M.C.M. (2004) Laccase production by Lepista 
sordida. Brazilian Journal of Microbiology, 35, 261-263.

Choi, J.H., Abe. N, Tanaka, H., Fushimi, K., Nishina, Y., Morita, A, Kiriiwa, Y., Motohashi, R., Hashizume, D., Koshino, H. and Kawagishi, H. (2010) Plant-Growth Regulator, Imidazole-4Carboxamide, Produced by the Fairy Ring Forming Fungus Lepista sordid. Journal of Agriculture and Food Chemistry, 58 (18), 9956-9959.

Contu, M. and Signorello, P. (1999) Contributo alla conoscenza della flora micologica (Macromiceti) delle dune della Sicilia. Bolletino della Accademia Giornia di Scienze Naturali Catania, 32(356),31-45.

Cooper, A.J. (2014) New species and combinations of some New Zealand agarics belonging to Clitopilus, Lyophyllum, Gerhardtia, Clitocybe, Hydnangium, Mycena, Rhodocollybia and Gerronema. Mycosphere, 5 (2), 263-288.

Davis, R.M., Sommer, R. and Menge, J.A .(2012) "Field Guid to Mushrooms of Western North America". University of California Press, Berkely, Los Angeles, California.

Dulger, B., Ergul, C.C. and Gucin, F. (2002) Antimicrobial activity of the macro fungus Lepista nuda. Fitoterapia, 73(7-8), 695-697.

Ekwebelam, S.A. (1980) Preliminary studies of inoculation of Pinus species with ectomycorrhizal fungi in Nigeria. Tropical Mycorrhiza Research, pp. $80-81$.

El-Fallal, A.A.(2003) Agaricales from the countryside and grasslands of East Delta region, Egypt. Journal of Environmental Sciences, 26(1), 339-350.

El-Fallal, A.A. (2013) Diversity of Macrofungi in the North Nile Delta. Third International Congress on Fungal Conservation, Akayaka, Mugla, Turkey, 1115 November, 2013.

El-Gharabawy, H., Detheridge, A., El-Fallal, A., ElSayed, A. and Griffith, G. (2016) Analysis of wood decay and ligninolysis in Polyporales from the Nile Delta region of Egypt. Mycosphere, 7, 392-404.

Garnica, S., Weiss, M., Walther, G. and Oberwinkler, F. (2007) Reconstructing the evolution of agarics from nuclear gene sequences and basidiospore ultrastructure. Mycological Research, 111, 1019-1029.

Lee, S.B. and Taylor, J.W. (1990) Isolation of DNA from fungal mycelia and single spore in: "PCR Protocol. A Guide to Method and Applications". Innis, M.A., Gelfand, D.H., Sninsky, J.J. \& White,
T.J. (Ed.), pp. 282-287. Academic Press, San Diego, California.

Malençon, G. and Bertault, R. (1970-1975) Flore des champignons supérieurs du Maroc. Tome I-II, Agaricales. Rabat.

Mazur, X., Becker, U., Anke, T. and Sterner, O. (1996) Two new bioactive diterpenes from Lepista sordida. Phytochemistry, 43(2), 405-407.

Miao, S., Mao, X., Pei, R., Miao, S., Xiang, C., Lv, Y., Yang, X., Sun, J., Jia, S. and Liu, Y. (2013) Antitumor activity of polysaccharides from Lepista sordida against laryngocarcinoma in vitro and in vivo. International Journal of Biological Macromolecules, 60, 235-240.

Moncalvo, J.M., Vilgalys, R., Redhead, S.A., Johnson J.E., James, T.Y. and Aime, M.C. (2002) One hundred and seventeen clades of euagarics. Molecular Phylogenetics and Evolution, 23, 357-400.

Moser, M. (1978) "Keys to Agarics and Boleti (Polyporales, Boletales, Agaricales, Russulales)". G. Kibby (Ed.), pp. 118. Roger Phillips. London.

Murcia, M,A., Martínez-Tomé, M., Jiménez, A.M., Vera, A.M., Honrubia, M. and Parras, P. (2002) Antioxidant activity of edible fungi (truffles and mushrooms): losses during industrial processing. Journal of Food Protection, 65(10),1614-1622.

Popich, L. (2014) Observation: Lepista sordida (Schumach.) Singer. Mushroom Observer, http:// mushroomobserver.org/179866?q=2SsE1.

Species Fungorum (2013) http://www.speciesfungorum. org $/$ Names/SynSpecies.asp?RecordID $=310080$

Stott, K.G. (1998) Characteristics of Australian edible fungi in the genus Lepista and investigation into factors affecting cultivation. Sydney, Australia. pp. 168. Dr. Philosophy Thesis. University of Western Sidney, Hawkesbury.

Stott, K., Desmerger, C. and Holford, P. (2005) Relationship among Lepista species determined by CAPS and RAPD. Mycological Research, 109(2), 205-211.

Tamura, K. and Nei, M. (1993) Estimation of the number of nucleotide substitutions in the control region of mitochondrial DNA in humans and chimpanzees. Molecular Biology and Evolution, 10, 512-526.

Tamura, K., Dudley, J., Nei, M. and Kumar, S. (2007) MEGA4: Molecular Evolutionary Genetics 
Analysis (MEGA) software version 4.0. Molecular Biology and Evolution, 24, 1596-1599.

Terashima, Y. and Fujiie, A. (2005) Development of a fairy ring caused by Lepista sordida on Zoysiagrass over an eight-year period. International Turfgrass Society Research Journal, 10, 251-257.

Terashima, Y. and Fujiie, A. (2007) Comparison of conditions for mycelial growth of Lepista sordida causing fairy rings on Zoysia matrella turf to those on Agrostis palustris turf. Mycoscience, 48, 365-372.

Thompson, J.D., Higgins, D.G. and Gibson, T.J. (1994) CLUSTAL W: Improving the sensitivity of progressive multiple sequence alignment through sequence weighting, positions-specific gap penalties and weight matrix choice. Nucleic Acids Research, 22, 4673-4680.

Thongbai, B., Wittstein, K., Richter, C., Miller, S.L., Hyde, K.D., Thongklang, N., Klomklung, N., Chukeatirote, E. and Stadler, M. (2017) Successful cultivation of a valuable wild strain of Lepista sordida from Thailand. Mycological Progress, 16, 311-323.

White, T.J., Bruns, T., Lee, S. and Taylor, J.W. (1990) Amplification and direct sequencing of fungal ribosomal RNA genes for phylogenetics. In: "PCR Protocols: A Guide to Methods and Applications". Innis, M.A.; Gelfand, D.H.; Sninsky, J.J. \& White, T.J. (Ed.), pp. 315-322. Academic Press, Inc., New York.

Young, T. (1994) "Common Australian Fungi: A Naturalist's Guide". Univ. New South Wales Press. Sydney.

Yu ,X.D., Deng, H. and Yao, Y.J .(2011) Leucocalocybe, a new genus for Tricholoma mongolicum (Agaricales, Basidiomycota). African Journal of Microbiology Research, 5(31), 5750-5756.

Zhong, W., Liu, N., Xie, Y., Zhao, Y., Song, X. and Zhong, W. (2013) Antioxidant and anti-aging activities of mycelial polysaccharides from Lepista

\section{ألتسجيل الأول لفطر Lepista sordida (Schumach) Singer في شمال شرق

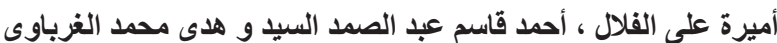

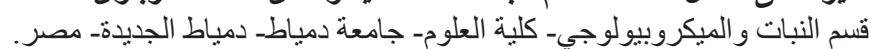

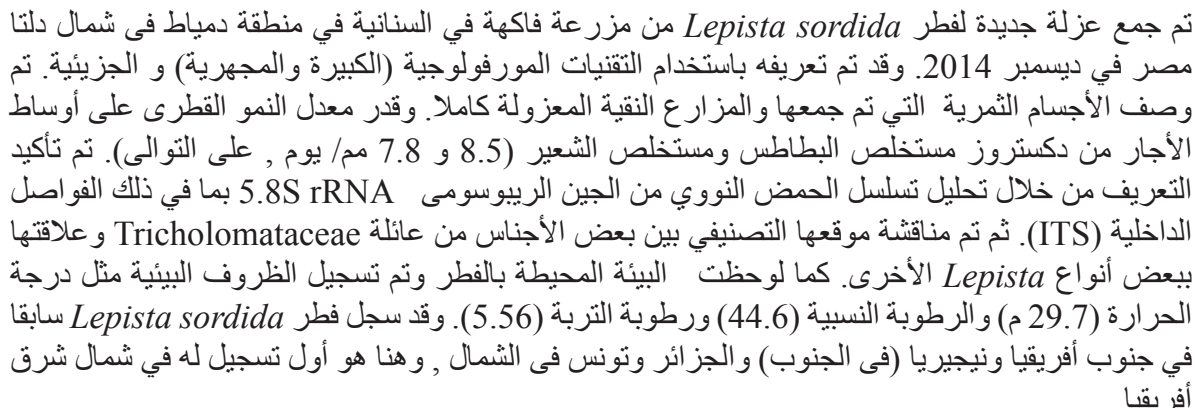

